\title{
Analisis Risiko Produksi Peternakan Ayam Broiler Di Kecamatan Sukowono Kabupaten Jember
}

\author{
Maryam Haniifah $^{1}$, Syamsul Hadi Kusuma ${ }^{2}$ \& Henik Prayuginingsih ${ }^{3}$ \\ Mahasiswa Program studi Agribisnis, Fakultas Pertanian, UM Jember ${ }^{1}$ \\ Dosen Program studi Agribisnis, Fakultas Pertanian, UM Jember ${ }^{2,3}$ \\ email: Maryamhaniifah@yahoo.co.id
}

\begin{abstract}
The study was conducted to examine the problemsed of broiler chicken farms at Sukowono District, Jember Regency. The research objectives are; (1) Identifying sources of production risk, (2) Knowing the opportunities for production risk, (3) Knowing the impact of production risk, (4) Formulate risk status and alternative strategies applied to overcome production risks. This type of research is descriptive and survey methods, using primary and secondary data with the location of the study chosen deliberately (purposive). Sampling uses the Total Sampling method. Data analysis using z-score, Value at Risk (VaR), risk status and risk map. Based on the results of the study, it could be concluded that; (1) Sources of production risk are diseases, rejected chickens, environmental disturbances and predatory pests, (2) Opportunities for production risk are environmental disorders of 62,17\%, reject chicken 59,87\%, pests and predators 57,14\%, and diseases 44,04\%, (3) The impact of the risk in the form of potential losses originating from the disease amounted to IDR 9.303.171, environmental disturbances amounting to IDR 6.814.817, reject chicken amounting to IDR 6.684 .948 and pests and predators of IDR 264.718 of 109.000 chickens, (4) Risk status for sources of risk of reject chicken and environmental disturbances is severe, for sources of risk of predatory diseases and pests are moderate. The results of risk mapping indicate that there are preventive and mitigation strategies. Environmental disorders and reject chicken are a source of risk that has a great opportunity and impact.
\end{abstract}

Keywords: Broiler chicken, Risk mapping, Production risk, Risk source.

\section{Pendahuluan}

Sub sektor peternakan menurut Arifin (2009) dalam Basuki (2016), merupakan suatu unit usaha agribisnis pertanian yang merupakan basis yang terintegrasi dengan pola keadaan lingkungan di Indonesia. Sub sektor peternakan harus dikembangkan sebagaimana prinsip agribisnis secara modern yang mengelola suatu unit usaha dari hulu ke hilir dengan meningkatkan keterkaitan antar komponen dan subsistem yang membangun suatu unit usaha agribisnis secara utuh. 
Salam (2009) menjelaskan pembangunan peternakan merupakan bagian dari pembangunan keseluruhan yang bertujuan untuk menyediakan pangan hewani berupa daging, susu, serta telur yang bernilai gizi tinggi, meningkatkan keuntungan peternak, serta menambah devisa dan memperluas kesempatan kerja.

Sutawi (2007), menyebutkan bahwa agribisnis ayam broiler merupakan usaha komersial yang dapat dilakukan secara massal, insentif, dan hemat lahan, sehingga peningkatan produksinya dapat dilakukan dalam waktu yang relatif cepat dan murah dibandingkan sumber protein hewani lainnya. Dewasa ini, pemeliharaan ternak unggas semakin meningkat, tidak hanya dikalangkan para peliharaan saja, tetapi masyarakat luas pun mulai menggemari ternak ini.

Pada Tabel 1.1 dapat dilihat bahwa pertumbuhan populasi tidak berpengaruh terhadap pertumbuhan produksi ayam broiler. Dari Tabel 1.1 dapat diketahui bahwa pertumbuhan populasi dari tahun ke tahun mengalami fluktuasi, sedangkan untuk produksi menunjukkan bahwa rata-rata pertumbuhan produksi ayam broiler di Indonesia tertinggi berada pada tahun 2016 sebesar 17,02\% dengan produksi sebanyak 1.905.497 ekor, sedangkan untuk rata-rata pertumbuhan terendah berada pada tahun 2017 sebesar $-3,01 \%$ dengan produksi sebanyak 1.848 .061 ekor.

Tabel 1.1 Populasi dan Produksi Ayam Broiler di Indonesia Tahun 2013-2017

\begin{tabular}{ccccc}
\hline Tahun & Populasi (Ekor) & Pertumbuhan $(\%)$ & $\begin{array}{c}\text { Produksi } \\
\text { (Ton) }\end{array}$ & $\begin{array}{c}\text { Pertumbuhan } \\
(\%)\end{array}$ \\
\hline 2013 & 1.344 .191 .104 & - & 1.497 .873 & - \\
2014 & 1.443 .349 .118 & 7,38 & 1.544 .379 & 3,10 \\
2015 & 1.528 .329 .183 & 5,89 & 1.628 .307 & 5,43 \\
2016 & 1.632 .567 .839 & 6,82 & 1.905 .497 & 17,02 \\
$2017^{*}$ & 1.698 .368 .741 & 4,03 & 1.848 .061 & $-3,01$ \\
\hline
\end{tabular}

Keterangan: *)angka sementara.

Sumber: Direktorat Jenderal Peternakan (2017).

Menurut Aziz (2009), risiko adalah kemungkinan kejadian yang menimbulkan kerugian. Setiap usaha pasti mengandung risiko, termasuk dalam agribisnis. Risiko dalam agribisnis diantaranya adalah risiko dalam hal produk dimana produk agribisnis tersebut gagal panen, rendahnya kualitas produk dan produk tersebut tidak dapat dijual, risiko karena kelangkaan bahan baku, risiko dalam hal teknologi seperti rusaknya mesin dan alat-alat pertanian serta terjadinya 
pencurian terhadap mesin dan alat-alat pertanian. Selain itu, risiko yang mungkin terjadi dalam dunia agribisnis adalah terjadinya risiko kredit macet.

Risiko menurut Djohanputro (2008), terkait dengan keadaan adanya ketidakpastian dan tingkat ketidakpastiannya terukur secara kuantitatif, menurut Kountur (2008) ada tiga unsur penting dari suatu kejadian yang dianggap risiko, yaitu: (1) Merupakan suatu kejadian, (2) kejadian tersebut masih merupakan kemungkinan, bisa terjadi bisa tidak, (3) jika sampai terjadi maka akan menimbulkan kerugian. Analisis risiko menurut Hanafi (2006) berhubungan dengan teori pengambilan keputusan (decision theory). Individu diasumsikan untuk bertindak rasional dalam mengambil keputusan bisnis.

Berdasarkan Tabel 1.3 menunjukkan bahwa produksi daging ayam terbesar yang dihasilkan di Kabupaten Jember adalah jenis ayam broiler dibandingkan dengan jenis lainnya, ini merupakan suatu hal positif dimana Kabupaten Jember merupakan salah satu Kabupaten yang berpotensi untuk dilakukan usaha ternak ayam broiler.

Tabel 1.3 Produksi Daging Ternak Unggas di Kabupaten Jember Tahun 2015-2017

\begin{tabular}{|c|c|c|c|c|c|}
\hline \multirow{2}{*}{ Jenis Ternak } & \multicolumn{3}{|c|}{ Jumlah Produksi (kg) } & \multirow{2}{*}{$\underset{\text { Rata-Rata }}{\sum \text { Produksi }}$} & \multirow{2}{*}{$\begin{array}{c}\text { Rata-rata } \\
\text { Kontribusi } \\
(\%)\end{array}$} \\
\hline & 2015 & 2016 & 2017 & & \\
\hline Ayam Buras & 2.615 .652 & 2.771 .735 & 2.709 .802 & 8.097 .189 & 12,91 \\
\hline Ayam Broiler & 18.810 .298 & 16.450 .002 & 16.804 .626 & 52.064926 & 82,98 \\
\hline Ayam Ras Petelur & 665.747 & 733.862 & 828.072 & 2.227 .681 & 3,55 \\
\hline Itik & 115.673 & 117.488 & 117.816 & 350.977 & 0,56 \\
\hline Jumlah & 22.209 .385 & 20.075 .103 & 20.462333 & 62.740 .773 & 1,00 \\
\hline
\end{tabular}

Jika dilihat dari besarnya kontribusi yang dihasilkan, komoditi ayam broiler memberikan rata-rata kontribusi terbesar terhadap jumlah produksi daging ternak unggas di Kabupaten Jember yaitu sebesar 82,98\% per tahun, namun di tahun 2016 terjadi penuruan produksi sebanyak $16.450 .002(\mathrm{~kg})$. Penurunan jumlah produksi pada daging ayam broiler ini mengindikasikan bahwa dalam melakukan usaha peternakan ayam broiler cukup berisiko, karena adanya tingkat kematian yang tinggi.

Kematian (mortalitas) merupakan suatu kejadian yang tidak dapat dihindarkan oleh para peternak ayam broiler, mengingat bahwa dalam melakukan 
usaha peternakan ayam broiler membutuhkan strategi penanganan khusus, agar kegiatan usaha tersebut dapat berjalan dengan lancar. Adanya jumlah produksi daging ayam broiler yang tinggi di Kabupaten Jember, menyebabkan banyak daerah di Kabupaten Jember berpotensi untuk menghasilkan ayam broiler dengan populasi yang tinggi, salah satunya adalah di Kecamatan Sukowono.

Berkaitan dengan peluang usaha yang terdapat pada budidaya ayam broiler, sejauh ini masyarakat serta peternak ayam broiler di Kecamatan Sukowono belum mengetahui secara pasti seberapa besar manfaat atau keuntungan yang diperoleh, karena keuntungan yang diperoleh peternak tidak menentu. Ada beberapa macam permasalahan yang dihadapi peternak ayam broiler di Kecamatan Sukowono yang berkaitan dengan keuntungan/profit.

Permasalahan utama yang dihadapi oleh peternak adalah masalah tingginya angka kematian (mortalitas) dan fluktuatifnya harga jual ayam. Berdasarkan data yang tersaji pada Tabel 1.5 populasi ayam broiler di Kecamatan Sukowono mengalami penurunan pada tahun 2014 dan 2017. Ayam sangat rentan akan penyakit, apabila peternak tidak cepat dalam mengatasi, ayam akan banyak yang mati dan ini menyebabkan kerugian bagi peternak, selain karena penyakit ayam, penyebab kematian ayam broiler adalah pemeliharaan yang harus dilakukan dengan baik.

Ada 3 hal penting dalam usaha ternak ayam broiler yang harus ditangani secara ketat, rutin dan teliti, yaitu: 1) pakan dan air, 2) obat, vitamin, sanitasi dan vaksin, serta 3) perkandangan. Bila tidak ada ketidaksempurnaan penanganan dari ketiga hal tersebut maka pengaruhnya terhadap pencapaian prestasi seperti tingkat pertumbuhan terhambat dan tingkat kematian tinggi (Priyono, 2009 dalam Basuki, 2016).

Menurut penelitian yang telah dilakukan oleh David (2013), sebaiknya mengutamakan strategi yang diakibatkan oleh sumber risiko penyakit. Hal tersebut dikarenakan tingkat kematian tertinggi diakibatkan oleh sumber risiko produksi penyakit. Agar strategi yang diberikan dapat memberikan hasil yang diinginkan, maka dibutuhkan koordinasi dari seluruh aspek manajemen mulai dari manajer, kepala kandang dan anak kandang. Kontribusi manajer pada peternakan dapat 
dilakukan dengan pemberian insentif bagi anak kandang yang berprestasi.

Adanya risiko yang dihadapi pada setiap periode produksi ayam broiler harus disertai dengan kemampuan peternak dalam mengelola risiko dengan baik, agar tidak menimbulkan kerugian. Risiko yang dihadapi oleh para peternak ayam broiler untuk menekan tingkat probabilitas atau peluang terjadinya risiko maupun dampak yang ditimbulkan oleh risiko tersebut. Melalui hasil analisis ini, diharapkan dapat meningkatkan kemampuan para peternak ayam broiler di Kecamatan Sukowono dalam menangani risiko yang dihadapi, sehingga mampu memperoleh tingkat keuntungan yang optimal.

Tabel 1.5 Populasi Ayam Broiler di Kecamatan Sukowono Kabupaten Jember Tahun 2013-2017

\begin{tabular}{ccc}
\hline Tahun & $\begin{array}{c}\text { Populasi } \\
\text { (Ekor) }\end{array}$ & $\begin{array}{c}\text { Pertumbuhan } \\
(\boldsymbol{\%})\end{array}$ \\
\hline 2013 & 34.000 & - \\
2014 & 32.000 & $-5,88$ \\
2015 & 32.000 & 0,00 \\
2016 & 88.978 & 178,06 \\
2017 & 83.456 & $-6,21$ \\
\hline
\end{tabular}
Sumber : BPS Kabupaten Jember (2014 s/d 2018).

Penelitian ini dilanjutkan dengan analisa kondisi eksternal dan internal dalam budidaya ayam broiler yang akan mempengaruhi keberlanjutan peternakan ayam broiler. Kondisi tersebut yang nantinya dijadikan bahan untuk analisa dan hasilnya digunakan untuk merumuskan suatu strategi penanganan risiko produksi pada usaha peternakan ayam broiler, agar usaha peternakan ayam broiler dapat tumbuh dan berkembang. Maka penelitian ini ditujukan untuk menganalisis risiko produksi peternakan ayam broiler di Kecamatan Sukowono sehingga peternak mampu mengetahui risiko produksi dan alternatif strategi yang tepat untuk usahanya, sehingga nantinya dapat meningkatkan keuntungan secara maksimal. Oleh karena itu, tujuan penelitian ini adalah untuk: (1) Mengidentifikasi sumber risiko produksi yang paling besar pengaruhnya pada peternakan ayam broiler di Kecamatan Sukowono; (2) Untuk mengetahui peluang risiko produksi pada usaha peternakan ayam broiler di Kecamatan Sukowono; (3) Untuk mengetahui dampak risiko produksi pada usaha peternakan ayam broiler di Kecamatan Sukowono; dan (4) 
Merumuskan status risiko dan alternatif strategi yang diterapkan untuk mengatasi risiko produksi yang dihadapi oleh peternakan ayam broiler di Kecamatan Sukowono.

\section{METODE PENELITIAN}

\section{Jenis dan Metode Penelitian}

Metode yang digunakan dalam penelitian ini adalah metode deskriptif dan metode survey. Menurut Suryabrata (1983), metode deskriptif digunakan untuk membuat pencandraan secara sistematis, faktual dan akurat mengenai fakta-fakta dan sifatsifat populasi atau daerah tertentu. Sementara itu, metode survey adalah metode yang mengambil sampel dari suatu populasi dan menggunakan kuesioner sebagai alat pengumpulan data yang pokok (Singarimbun, 2006).

\section{Penentuan Lokasi Penelitian}

Penentuan lokasi penelitian ini ditentukan secara sengaja (Purposive Method). Daerah penelitian yang dipilih adalah di Kecamatan Sukowono Kabupaten Jember.

\section{Metode Pengambilan Sampel}

Metode yang digunakan dalam pengambilan sampel adalah Total Sampling, yaitu keseluruhan populasi sebanyak 21 peternak, adapun responden peternak ayam broiler terletak di Desa Sukorejo, Desa Sukosari, Desa Sumberwringin, Desa Mojogemi, Desa Sukokerto, Desa Arjasa, Desa Baletbaru dan Desa Sumberwaru.

\section{Metode Pengumpulan Data}

Data yang digunakan adalah data primer dan data sekunder, kedua data ini bersifat kuantitatif dan kualitatif. Data primer diperoleh secara langsung dari peternak responden melalui wawancara. Data sekunder diperoleh melalui data dokumentasi perusahaan, jurnal peternakan ayam, BPS Kecamatan Sukowono, Dinas Peternakan dan Perikanan Kabupaten Jember, perpustakaan, buku-buku ekonomi dan pertanian dll.

\section{Metode Analisis Data}

Metode analisis data yang digunakan untuk menguji hipotesis dalam penelitian adalah:

1. Untuk menguji hipotesis pertama yaitu mengenai peluang risiko produksi digunakan analisis z-score dengan formulasi sebagai berikut: 


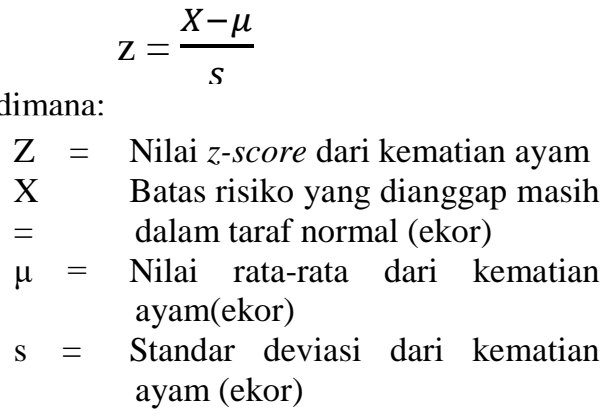

2. Untuk menguji hipotesis pertama yaitu mengenai peluang risiko produksi digunakan analisis z-score dengan formulasi sebagai berikut:

dimana:

$$
\mathrm{VaR}=\mathrm{x}+\mathrm{z}\left(\frac{s}{\sqrt{n}}\right)
$$

$$
\begin{aligned}
\text { VaR = } & \begin{array}{l}
\text { Dampak kerugian } \\
\text { ditimbulkan oleh } \\
\text { berisiko peternakan } \\
\text { kejadian }
\end{array} \\
& \text { ayam broiler di Kecamatan } \\
& \text { Sukowono (rupiah). } \\
\mathrm{x}= & \text { Nilai rata-rata kerugian akibat } \\
& \text { kejadian berisiko peternakan } \\
& \text { ayam broiler di Kecamatan } \\
& \text { Sukowono (ekor) } \\
\mathrm{z}= & \text { Nilai z yang diambil dari tabel } \\
& \text { distribusi normal dengan alfa 5 } \\
& \text { persen } \\
\mathrm{s}= & \text { Standar deviasi kerugian akibat } \\
& \text { kejadian berisiko peternakan } \\
& \text { ayam broiler di Kecamatan } \\
& \text { Sukowono. } \\
\mathrm{n}= & \text { Jumlah responden peternakan } \\
& \text { ayam broiler di Kecamatan } \\
& \text { Sukowono. }
\end{aligned}
$$

\section{Hasil Dan Pembahasan}

\section{Identifikasi Sumber-sumber Risiko Produksi}

Identifikasi sumber-sumber risiko produksi pada peternakan ayam broiler yang berlokasi di Kecamatan Sukowono dilakukan dengan melakukan wawancara dengan peternak dan juga pengamatan pada 21 kandang peternakan ayam broiler di daerah tersebut. Adapun sumber risiko tersebut yaitu: (1) Penyakit, (2) Ayam Afkir, (3) Gangguan Lingkungan, dan (4) Hama dan Predator.

Adapun Penyakit yang menyerang adalah penyakit gumboro (infectious 
bursal disease) dan malaria unggas (leucositizoonosis). penyakit yang menjadi penyebab utama kematian ayam adalah gumboro (infectious bursal disease). Gejala dari penyakit ini adalah hilangnya nafsu makan ayam, peradangan di sekitar dubur, dan diare. Penyakit ini sulit untuk diobati sehingga jika sudah terkena penyakit ini maka ayam akan mati. Selain sulit diobati, penyakit gumboro juga dapat menular dengan cepat melalui kotoran, pakan, minuman dan peralatan lain yang sudah tercemar. Selain itu penyakit lain yang menyebabkan kematian ayam broiler di Kecamatan Sukowono adalah penyakit malaria unggas (Leucocytozoonosis) adalah penyakit yang disebabkan oleh nyamuk yang menyebabkan infeksi pada saluran pernafasan. Gejala dari penyakit ini adalah adanya muntah darah, kejang-kejang lalu ambruk disertai leleran darah segar di lubang hidung atau paruh.

Adanya ayam afkir menjadi salah satu penyebab sumber risiko yang merugikan peternak. Ayam afkir terlihat dari adanya kondisi fisik ayam yang kerdil dan cacat serta pertumbuhannya yang lambat. Selain itu ditemukan pula ayam dengan kondisi kaki yang lemah akibat dari ketidakmampuan ayam untuk bertahan sehingga ayam menjadi mudah stres. Ayam broiler yang afkir dihitung sebagai ayam broiler yang sudah mati oleh para peternak.

Menurut peternak ayam broiler di Kecamatan Sukowono suara keras, misalnya suara petir ataupun sound musik pernah menyebabkan kematian pada ayam. Selain itu, keadaan litter yang basah juga dapat menyebabkan kematian ayam, karena kondisi litter yang basah dapat mengakibatkan tingginya tingkat amoniak yang dapat mengakibatkan kematian ayam serta sistim panen atau proses penangkapan ayam yang salah dapat menyebabkan ayam menjadi stres dan menyebabkan kematian pada ayam.

Hama yang sering menyerang pada peternakan ayam broiler di Kecamatan Sukowono adalah tungau. Tungau tidak menyebabkan kematian pada ayam akan tetapi dapat membuat ayam gelisah, nafsu makan menurun dan ayam menjadi kurus. Selain hama, faktor lain yang dapat mengganggu proses budidaya ayam broiler adalah predator. Predator yang sering memangsa ayam di Kecamatan Sukowono adalah kucing, predator tersebut biasanya selalu menyerang ayam broiler terutama pada saat ayam berumur 0-2 minggu. 


\section{Analisis Probabilitas Risiko}

Probabilitas risiko adalah peluang terjadinya risiko yang mendatangkan akibat positif maupun negatif. Tabel 6.18 menunjukkan bahwa peluang atau probabilitas risiko produksi pada peternakan ayam broiler di Kecamatan Sukowono yaitu

Tabel 6.18 Perhitungan Status Sumber Risiko Pada Peternakan Ayam Broiler di Kecamatan Sukowono

\begin{tabular}{lccc}
\hline Sumber Risiko & $\begin{array}{c}\text { Probabilitas } \\
(\mathbf{\%})\end{array}$ & $\begin{array}{c}\text { Dampak Risiko } \\
(\mathbf{R p )}\end{array}$ & Status Risiko \\
\hline Penyakit & 44,04 & 9.303 .171 & 4.097 .116 \\
Ayam afkir & 59,87 & 6.684 .948 & 4.002 .279 \\
Gangguan lingkungan & 62,17 & 6.814 .817 & 4.236 .905 \\
Hama dan predator & 57,14 & 264.718 & 151.266 \\
\hline Rata-rata & $\mathbf{5 5 , 8 1}$ & $\mathbf{5 . 7 6 6 . 9 1 4}$ & $\mathbf{3 . 1 2 1 . 8 9 1}$ \\
\hline
\end{tabular}

Sumber: Analisis Data Primer (2019).

\section{Analisis Dampak Risiko Produksi}

Dampak risiko adalah pengaruh risiko yang mendatangkan akibat positif maupun negatif. Perhitungan yang dilakukan terhadap dampak risiko produksi yang terjadi pada peternakan ayam broiler di Kecamatan Sukowono menggunakan tingkat keyakinan $95 \%$ dan $5 \%$ sisanya adalah error. Harga jual ayam pada masing-masing peternakan berbeda-beda. Untuk menghitung dampak dari risiko produksi harga yang digunakan adalah harga jual rata-rata dari ke 21 peternakan. Hasil perhitungan menunjukkan bahwa harga jual rata rata ayam pada ke 21 responden adalah Rp 17.864. Berdasarkan Tabel 6.18 dampak risiko produksi berupa potensi kerugian pada peternakan ayam broiler di Kecamatan Sukowono berasal dari penyakit sebesar Rp 9.303.171, gangguan lingkungan sebesar Rp 6.814.817 dan ayam afkir sebesar Rp 6.684 .948 serta berasal dari hama dan predator sebesar Rp 264.718 dari 109.000 ekor ayam.

\section{Pemetaan Risiko Produksi}

Pemetaan risiko ini dilakukan dengan cara memplotkan sumber risiko masing-masing yang telah diukur dari segi kemungkinan maupun dampaknya ke dalam dua sumbu yaitu sumbu vertikal yang menggambarkan probabilitas dan sumbu horizontal yang menggambarkan dampak.

Masing-masing sumber risiko yang akan dipetakan ditempatkan berdasarkan 
posisinya dari hasil perhitungan probabilitas dan dampak sehingga akan diketahui status dari risiko tersebut. Status risiko dapat dicari dengan melakukan perkalian antara probabilitas masing-masing sumber risiko dengan dampak yang disebabkan oleh sumber risiko tersebut. Status risiko ini akan menunjukkan urutan kejadian dari mulai yang berisiko besar hingga yang berisiko kecil.

Batas tingkat probabilitas dan dampak risiko yang dianggap besar dan kecil, didapat dari hasil rata-rata probabilitas dan dampak risiko dari semua sumber risiko di Kecamatan Sukowono. Berdasarkan hasil perhitungan pada Tabel 6.18, diperoleh nilai rata-rata sebesar 55,81 persen yang kemudian di konfirmasikan terhadap para responden peternak di Kecamatan Sukowono untuk dilakukan pembulatan menjadi 56 persen, sedangkan batas dampak kerugiannya adalah sebesar Rp 5.766.914 yang kemudian di dilakukan pembulatan menjadi $\mathrm{Rp}$ 6.000.000.

Pemetaan risiko ini sangat diperlukan dalam penentuan prioritas dalam penanganan sumber-sumber risiko. Pemetaan risiko dilakukan berdasarkan status risiko. Status risiko dapat menunjukkan sumber risiko mana yang berpeluang memberikan kerugian terbesar bagi peternakan. Prioritas penanganan dari masingmasing sumber risiko dapat ditentukan dengan terlebih dahulu mencari status risiko. Urutan status risiko tersebut dapat menjadi acuan bagi manajemen peternakan dalam menentukan strategi dalam mengurangi probabilitas dan dampak yang disebabkan oleh masing-masing sumber risiko.

Berdasarkan Tabel 6.18 dapat diketahui urutan sumber risiko produksi pada peternakan ayam broielr di Kecamatan Sukowono dari yang paling besar (paling berisiko), dengan status risiko sebesar 4.097.116, diikuti dengan sumber risiko gangguan lingkungan sebesar 4.236.905 dan sumber risiko ayam afkir sebesar 4.002.279. hama dan predator merupakan sumber risiko produksi yang memiliki status risiko terkecil (paling tidak berisiko) yaitu sebesar 151.266.

Batas status risiko yang dianggap normal oleh para peternak yang berada di Kecamatan Sukowono diperoleh dari nilai rata-rata status risiko yang didapat dari hasil rata-rata status risiko setiap sumber risiko. Status risiko yang dapat dianggap masih normal adalah 4.236.905 pada satu siklus produksi. 
Tabel 6.19. Hasil Penggolongan Kategori Status Risiko Produksi Pada Peternakan Ayam Broiler di Kecamatan Sukowono, Tahun 2019

\begin{tabular}{lc}
\hline \multicolumn{1}{c}{ Sumber Risiko } & Kategori Status Risiko \\
\hline Penyakit & Sedang \\
Ayam Afkir & Berat \\
Lingkungan & Berat \\
Hama Predator & Sedang \\
\hline
\end{tabular}

Sumber: Analisis Data Primer (2019).

Tabel 6.19 menunjukkan bahwa hasil penggolongan kategori status risiko untuk sumber risiko ayam afkir dan gangguan lingkungan adalah berat, sedangkan untuk sumber risiko penyakit dan hama predator tergolong status sedang.

Berdasarkan Gambar 6.1 dapat dilihat bahwa sumber-sumber risiko seperti hama dan predator berada pada kuadran satu, sumber risiko ayam afkir dan gangguan lingkungan berada pada kuadran dua dimana masing-masing kuadran memiliki probabilitas diatas batas yang dianggap normal yaitu 56 persen. Sedangkan sumber risiko penyakit berada pada kuadran empat yaitu kuadran yang memiliki probabilitas dibawah batas yang dianggap normal yaitu 56 persen.

Jika dilihat dari segi dampak yang disebabkan, ada satu sumber risiko yang memberi dampak dibawah batas normal yang dapat ditolerir oleh perusahaan yaitu sumber risiko hama dan predator. Sedangkan tiga sumber risiko lain yaitu ayam afkir, gangguan lingkungan serta penyakit memberi dampak diatas batas normal yaitu berada di kuadran dua dan kuadran empat. Seperti pada Gambar 6.1 dapat dilihat bahwa kuadran dua dan empat merupakan kuadran dimana dampak yang disebabkan lebih besar dibandingkan dengan batas normal yang masih mampu ditolerir oleh peternakan.

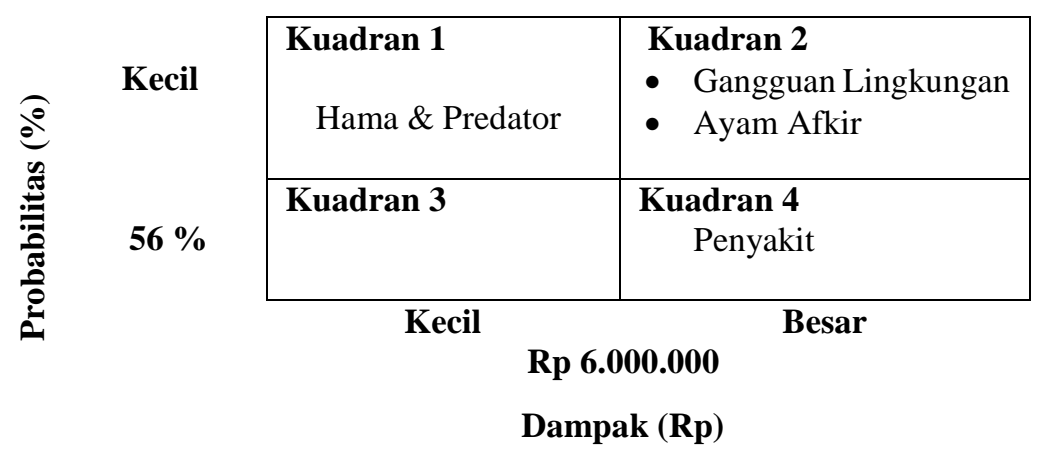

Gambar 6.1 Hasil Pemetaan Sumber-sumber Risiko Produksi pada Peternakan Ayam Broiler di Kecamatan Sukowono

(Sumber: Analisis Data Primer, Tahun 2019) 


\section{Strategi Penanganan Risiko}

Penanganan risiko adalah suatu usaha untuk mengetahui, menganalisis serta mengendalikan risiko dalam setiap kegiatan perusahaan dengan tujuan untuk efektifitas dan efisiensi yang lebih tinggi. Karena itu perlu terlebih dahulu memahami tentang konsep-konsep yang dapat memberi makna, cakupan yang luas dalam rangka memahami proses penangan tersebut. Hal ini sesuai dengan defenisi yang di tetapkan oleh Darmawi (2005). Terdapat dua alternatif strategi dalam mengurangi probabilitas dan dampak risiko yaitu:

\section{Strategi Preventif}

Strategi preventif dilakukan untuk menangani sumber risiko produksi yang terletak pada kuadran 1 dan 2. Pada kuadran satu yaitu risiko hama dan predator dan pada kuadran dua yaitu risiko ayam afkir, dan gangguan lingkungan (Gambar 6.1).

Hama pada peternakan ayam di Kecamatan Sukowono adalah berupa tungau. Sedangkan predator yang menjadi penyebab kematian ayam di Kecamatan Sukowono adalah kucing. Kucing masuk ke kandang melalui celah yang ada pada kandang yaitu celah yang berada antara atap kandang dengan dinding kandang dan juga melalui celah yang ada pada dinding kandang. Upaya pengurangan kematian ayam akibat hama predator dapat dilakukan dengan salah satu upaya yaitu isolasi. Isolasi yang dilakukan adalah dengan menutup celah yang memungkinkan kucing dapat masuk ke dalam kandang. Upaya ini merupakan cara terbaik yang dapat dilakukan karena jika melakukan penjagaan akan sangat sulit karena predator biasanya menyerang ayam pada malam hari. Selain melakukan isolasi dapat dilakukan dengan memberikan jaring kawat pada seluruh bagian kandang dan memasang perangkap terhadap kucing.

Stres pada ayam dapat terjadi karena ayam tidak mampu beradaptasi dengan lingkungan baru pada saat masih DOC. Selain tidak mampu beradaptasi, suarasuara keras seperti petir ataupun akibat cuaca ekstrim juga dapat menyebabkan stres dan kematian pada ayam dan keadaan suhu dalam kandang. Sistem pemanenan ayam dapat juga menjadi faktor penyebab kematian ayam. Selain itu pada peternakan di Kecamatan Sukowono orang-orang yang tidak berkepentingan bebas 
keluar masuk ke dalam kandang. Strategi preventif yang dapat dilakukan untuk mengatasi kematian akibat gangguan lingkungan adalah dengan memberikan vitamin. Pemberian vitamin dapat dilakukan setelah DOC tiba ke kandang. Pemberian vitamin dapat mengurangi stes pada ayam karena lingkungan baru. Sistem pemanenan ayam juga perlu diperhatikan. Sebaiknya ayam yang akan dipanen terlebih dahulu dipisahkan dengan ayam yang belum dipanen. Dengan demikian ayam yang tidak dipanen pada waktu tersebut tidak stess. Melakukan pembersihan secara intensif terhadap kandang. Selain itu, pada saat cuaca panas dapat dicegah dengan melakukan sirkulasi kandang yang baik dan melakukan sistim buka tutup tirai kandang dengan menyesuaikan dengan kondisi cuaca.

Strategi yang dapat diterapkan oleh para peternak dalam mengatasi ayam afkir adalah dengan membentuk kelompok peternak, sehingga dapat memperkuat posisi tawar para peternak. Melalui kelompok tersebut, para peternak dapat mengajukan complaint kepada pihak inti agar dapat melakukan pemotongan harga DOC apabila ditemui sejumlah ayam broiler yang afkir. Dengan demikian, dapat membuat pihak inti mengupayakan memberikan DOC yang berkualitas baik sehingga tidak ditemukan lagi sejumlah ayam yang afkir.

\section{Strategi Mitigasi}

Strategi mitigasi dilakukan untuk menangani sumber risiko produksi yang terdapat pada kuadran 2 dan 4. Pada kuadran 2 sumber risiko produksi yang harus ditangani adalah ayam afkir dan gangguan lingkungan, sedangkan pada kuadran 4 sumber risiko yang ditangani adalah penyakit.

Melakukan pengecekan tirai saat ayam broiler mengalami kematian akibat suhu udara yang tidak ideal dan melakukan pemberian multivitamin DOC. Jika dalam melakukan seleksi awal masuk DOC kedalam kandang melakukan tindakan kecerobohan sehingga ada DOC yang mati saat dipelihara karena kulitas DOC yang rendah, strategi yang dijalankan oleh peternak di Kecamatan Sukowono yaitu dengan memberikan multivitamin kepada DOC yang berkualitas rendah, tindakan ini merupakan pengurangan jumlah kematian dari ayam broiler yang dipelihara. Strategi ini sudah dijalankan oleh para peternak yang berada di Kecamatan Sukowono. Selain itu para peternak juga melakukan pengecekan dan pengontrolan 
ayam dan kandang maupun di lingkungan kandang setiap hari, upaya ini dilakukan untuk memperkecil tingkat kematian ayam. Strategi ini sudah dijalankan oleh para peternak yang berada di Kecamatan Sukowono.

Upaya untuk memperkecil dampak akibat sumber risiko ayam broiler afkir pun dapat dilakukan oleh peternakan ayam broiler di Kecamatan Sukowono. Upaya tersebut adalah dengan melakukan pemisahan antara ayam broiler yang afkir dengan ayam broiler lainnya ke dalam kandang khusus. Pemisahan tersebut dilakukan untuk menghindari penyebaran penyakit, karena ayam broiler yang afkir lebih rentan terserang penyakit. Adapun upaya lainnya yang telah dilakukan oleh peternak ayam broiler di Kecamatan Sukowono yakni dengan menjual ayam afkir dengan harga murah.

Berdasarkan hasil pemetaan risiko, sumber risiko serangan penyakit berada di kuadran 4. Tingkat probabilitas sumber risiko serangan penyakit adalah sebesar 44,04 persen, sedangkan dampak yang ditimbulkan adalah sebesar Rp.9.303.171. Adapun status risiko yang dihasilkan adalah sebesar 4.097.116 (Tabel 6.18). Alternatif manajemen yang diusulkan untuk mengurangi dampak yang ditimbulkan akibat sumber risiko serangan penyakit adalah dengan melakukan perawatan yang lebih intensif pada ayam broiler yang terserang penyakit. Ayam broiler yang terserang penyakit dirawat di tempat yang terpisah dari ayam broiler yang sehat. Selain itu pengobatan secara herbal pun dapat dilakukan oleh para peternak ayam broiler di Kecamatan Sukowono dengan memberikan vitamin yang telah dicampur dengan larutan temulawak, bawang merah dan daun mimba pada setiap ayam broiler yang terserang penyakit malaria unggas. Selain pengobatan herbal, dapat juga melakukan pemberian vaksin ataupun obat pada ayam broiler yang terserang penyakit.

\section{SIMPULAN}

Berdasarkan perumusan masalah, tujuan penelitian, hipotesis, dan hasil penelitian serta pembahasan, maka dapat disimpulkan bahwa:

1. Sumber risiko produksi yang terjadi pada budidaya peternakan ayam broiler di

Kecamatan Sukowono adalah serangan penyakit, ayam afkir, gangguan lingkungan serta hama dan predator. 
2. Peluang atau probabilitas risiko produksi pada peternakan ayam broiler di Kecamatan Sukowono yaitu gangguan lingkungan sebesar 62,17\%, ayam afkir $59,87 \%$, hama dan predator $57,14 \%$, dan serangan penyakit $44,04 \%$.

3. Dampak dari semua sumber risiko berupa potensi kerugian berasal dari penyakit sebesar Rp 9.303.171, gangguan lingkungan sebesar Rp 6.814.817 dan ayam afkir sebesar Rp 6.684 .948 serta berasal dari hama dan predator sebesar Rp 264.718 dari 109.000 ekor ayam.

4. Status risiko menunjukkan bahwa hasil penggolongan kategori status risiko untuk sumber risiko ayam afkir dan gangguan lingkungan adalah berat, sedangkan untuk sumber risiko penyakit dan hama predator tergolong status sedang. Alternatif untuk menanggulangi sumber risiko yang terjadi pada budidaya ayam broiler di Kecamatan Sukowono yaitu strategi preventif dengan cara melakukan seleksi awal pemilihan DOC yang berkualitas, memberikan multivitamin, pihak perusahaan inti memberikan informasi kepada peternak mengenai ramalan cuaca, memberikan minuman yang telah dicampur dengan ramuan tradisional, memasang alat pengukur suhu udara, membersihkan kandang dan alat-alat produksi, dan memberikan vaksin.

\section{DAFTAR PUSTAKA}

Aziz, F. 2009. Analisis Risiko Dalam Usahaternak Ayam Broiler (Studi Kasus Usaha Peternakan X di Desa Tapos, Kecamatan Tenjo, Kabupaten Bogor. Skripsi (dipublikasikan). Fakultas Ekonomi dan Manajemen. Institut Pertanian Bogor. Bogor. Retrieved from http://repository.ipb.ac.id.

Basuki, F. 2016. Analisis Kelayakan Finansial dan Prospek Pengembangan Peternakan Ayam Ras Pedaging di Kecamatan Sukowono Kabupaten Jember. Skripsi (dipublikasikan). Fakultas Pertanian. Universitas Jember. Jember. Retrieved from http://repository.unej.ac.id.

BPS. 2015. Kabupaten Jember Dalam Angka 2016. Kabupaten Jember. Jember.

_. 2016. Kabupaten Jember Dalam Angka 2017. Kabupaten Jember. Jember.

_. 2017. Kabupaten Jember Dalam Angka 2018. Kabupaten Jember. Jember.

Darmawi, H. 2005. Manajemen Risiko. Jakarta: Bumi Aksara. 
David, M. 2013. Analisis Risiko Produksi Pada Peternakan Ayam Broiler di Kampung Kandang, Desa Tegal, Kecamatan Kemang, Kabupaten Bogor, Jawa Barat. Skripsi (dipublikasikan). Fakultas Ekonomi dan Manajemen. Institut Pertanian Bogor. Bogor. Retrieved from https://repository.ipb.ac.id.

Ditjen Peternakan. 2017. Populasi Ayam Ras Pedaging Indonesia. Direktoral Jenderal Peternakan.

Djohanputro, B. 2008. Manajemen Risiko Korporat Terintegrasi. Jakarta: PPM.

Kontur, R. 2008. Mudah Memahami Manajemen Risiko Perusahaan. Jakarta: CV.Teruna Grafica.

Salam, T. 2009. Analisis Finansial Peternakan Ayam Broiler Pola Kemitraan. Jurnal Agrisistem, Juni 2006, Vol 2 No. 1. Halaman 33.

Singarimbun, dkk. 2006. Metode Penelitian Survei (Editor). Jakarta: LP3ES.

Suryabrata, S. 1983. Metodologi Penelitian. CV. Rajawala. Jakarta.

Sutawi. 2007. Agribisnis Peternakan. Kapita Selekta. Skripsi (dipublikasikan). Fakultas Pertanian. Universitas Malang. Malang. Retrieved from http://repository.umm.ac.id. 